УДК 330.322:656.2

\title{
МЕХАНІЗМ УПРАВЛІННЯ ІНВЕСТИЦІЙНОЮ ДІЯЛЬНІСТЮ НА ПІДПРИЕМСТВАХ ЗАЛІЗНИЧНОГО ТРАНСПОРТУ
}

\author{
Дараган О.О., аспірант (УкрДАЗТ)
}

\begin{abstract}
В статті досліджено сутність механізму управління інвестиційною діяльністю підприємств залізничного транспорту, визначено його основні складові, серед яких традиційні компоненти системи управління: планування, аналіз, організація, оцінка, контроль та мотиваџія інвестиційної діяльності, а також механізми залучення інвестицій, розподілу інвестищійних ресурсів, державної підтримки, впровадження організаџійно-управлінських інноваџій, активізаџії інвестииійної діяльності та забезпечення інвестиційної привабливості. Проаналізовано джерела та інструменти інвестування на залізничному транспорті, запропоновано напрямки удосконалення управління інвестиційною діяльністю на підприємствах залізничної галузі.
\end{abstract}

Ключові слова: інвестиції, інвестиційна діяльність, механізм, управління, підприємства залізничного транспорту.

\section{МЕХАНИЗМ УПРАВЛЕНИЯ ИНВЕСТИЦИОННОЙ ДЕЯТЕЛЬНОСТЬЮ НА ПРЕДПРИЯТИЯХ ЖЕЛЕЗНОДОРОЖНОГО ТРАНСПОРТА}

\author{
Дараган А.О., аспирант (УкрГАЖТ)
}

В статье исследована сущность механизма управления инвестиционной деятельностью предприятий железнодорожного транспорта, определены его основные составляющие, среди которых традиционные компоненты системы управления: планирование, анализ, организация, оценка, контроль и мотивация инвестиционной деятельности, а также механизмы привлечения инвестиций, распределения инвестииионных ресурсов, государственной поддержки, внедрения организационно-управленческих инноваций, активизации инвестиционной деятельности и обеспечения инвестиционной привлекательности. Проанализированы источники и инструменты инвестирования на железнодорожном транспорте, предложень направления усовершенствования управления инвестиционной деятельностью на предприятиях железнодорожной отрасли.

Ключевые слова: инвестиции, инвестиционная деятельность, механизм, управление, предприятия железнодорожного транспорта.

\section{MECHANISM OF MANAGEMENT BY INVESTMENT ACTIVITY ON ENTERPRISES OF RAILWAY TRANSPORT}

\author{
Daragan O.O., post- graduate (USA of RT)
}

The article studies the essence of the mechanism of management of investment activity of enterprises of railway transport, identifies its main components, among which the traditional control system components are: planning, analysis, organization, evaluation, supervision and motivation of investment activity, as well as mechanisms to attract investments, the allocation of investment resources, state support, implementation of organizational and managerial innovation, increasing investment activity and ensuring investment attractiveness. Analyzed the sources and instruments of investing in rail transport, the directions of improvement of management of investment activity of the enterprises of the railway sector, including through the development of public-private partnerships and strengthening the state support. The conclusion about necessity of transition of the investment mechanism in a more flexible, mobile form of functioning that will help him / her under the present conditions of farming.

Keywords: investments, investment activity, mechanism, management, railway transport enterprise.

Постановка проблеми та ї̈ зв'язки 3 науковими чи практичними завданнями. Для забезпечення економічного підйому залізничного транспорту необхідно сформувати достатні інвестиційні ресурси для підвищення якості транспортного обслуговування, скорочення експлуатаційних витрат, зростання продуктивності праці та фондовіддачі при перевезенні вантажів та пасажирів, розвитку системи інформаційного забезпечення 3 метою підвищення ефективності 
управління перевізним процесом, впровадження ресурсозберігаючих технологій, оснащення рухомими складом нового покоління, соціального захисту працівників залізничної галузі, а також для реалізації стратегічно значимих масштабних проектів, зокрема впровадження швидкісного руху. Зазначене обумовлює необхідність формування ефективного механізму управління інвестиційної діяльністю на підприємствах залізничного транспорту.

Аналіз останніх досліджень $і$ публікацій. Теоретичні підходи та практичні рекомендації щодо розвитку інвестиційних процесів на підприємствах залізничного транспорту знайшли своє відображення працях таких науковців як: Дикань В.Л., Зубенко В.О., Ільчук В.П., Сич Є.М., Калініченко Л.Л. та інших [1-3], у тому числі механізм інвестування підприємств залізничної галузі вивчали такі вчені як: Андрєєва О.В., Долгий А.О., Долгий О.О., Манзюк В.В., Лоза С.П. та інші [4-6].

Виділення невирішених частин загальної проблеми. Однак питання удосконалення механізму інвестиційної діяльності на підприємствах залізничного транспорту залишається актуальним i своєчасним, а тому потребує подальшого дослідження.

Метою статmi $€$ обгрунтування складових елементів механізму управління інвестиційною діяльністю на підприємствах залізничного транспорту та визначення шляхів удосконалення інвестиційної діяльності.

Виклад основного матеріалу.

Забезпечення розвитку підприємств залізничного транспорту й їх ефективна діяльність в довгостроковій перспективі, а також підвищення конкурентоспроможності значною мірою визначаються рівнем інвестиційної активності i масштабами інвестиційної діяльності, котрі у свою чергу залежать від ефективності механізму управління цією діяльністю.

Стосовно інвестиційної діяльності поняття «механізм» використовується в різних контекстах. Більшість вчених [7, 8] вважають, що «механізм інвестиційного менеджменту» - це система основних елементів, регулюючих процес розробки і реалізації інвестиційних рішень підприємства. До числа основних елементів механізму відносяться: ринковий механізм регулювання інвестиційної діяльності підприємства; державне нормативноправове регулювання інвестиційної діяльності; внутрішній механізм регулювання, система конкретних методів здійснення управління інвестиційної діяльності.

На думку Аюпової Л.К. [9] слід виділяти організаційний i економічний механізм інвестиційної діяльності підприємства. Під економічним механізмом інвестиційної діяльності автор розуміє інтегровану багаторівневу систему форм i методів зовнішніх i внутрішніх економічних відносин між учасниками інвестиційного процесу, котра включає способи оцінки інвестиційної діяльності 3 урахуванням ринкової кон'юнктури, регульовану за допомогою мотиваційного, ресурсного, правового i методичного забезпечення.

Андрєєва О.В. [4] під механізмом інвестування на залізничному транспорті розуміє цілеспрямоване поєднання форм i методів галузевого інвестування, що забезпечується шляхом реалізації концепції інвестиційного контролінгу та наявності функціональних підсистем - моніторингу та діагностики факторів внутрішнього та зовнішнього середовища, фінансового прогнозування і планування, організації, ресурсного забезпечення (в тому числі фінансового), обліку, аналізу, контролю за протіканням інвестиційного процесу тощо.

Можна констатувати, що механізм управління інвестиційною діяльністю охоплює традиційні компоненти системи управління, серед яких планування, аналіз, організація, контроль, оцінка, мотивація інвестиційної діяльності. Крім того, включає специфічні набори інструментарію залучення інвестицій, відрізняється моделями розподілу інвестиційних ресурсів, напрямками активізації інвестиційної діяльності та чинниками забезпечення інвестиційної привабливості.

Таким чином, механізм управління інвестиційної діяльності на підприємствах залізничної галузі, визначається як сукупність організаційно-економічних форм i методів, інструментів і важелів дії на інвестиційну діяльність, взаємопов'язаних в єдиний механізм, що припускає мотиваційне, правове, ресурсне і методичне забезпечення, котрий дозволяє визначити обсяг, структуру, напрями і реалізацію інвестицій 3 метою досягнення максимального корисного ефекту i забезпечення стабільної фінансово-господарської діяльності підприємств залізничного транспорту в найближчій і подальшій перспективі.

Слід зазначити, що даний механізм $\epsilon$ складовою фінансово-економічного системи галузі, рушійним елементом останнього $\epsilon$ інвестиційна галузева політика, котра сформована у відповідності із засадами розвитку економічної системи країни та реформ, що його супроводжують.

Основні складові механізму управління інвестиційною діяльністю представлено на рис. 


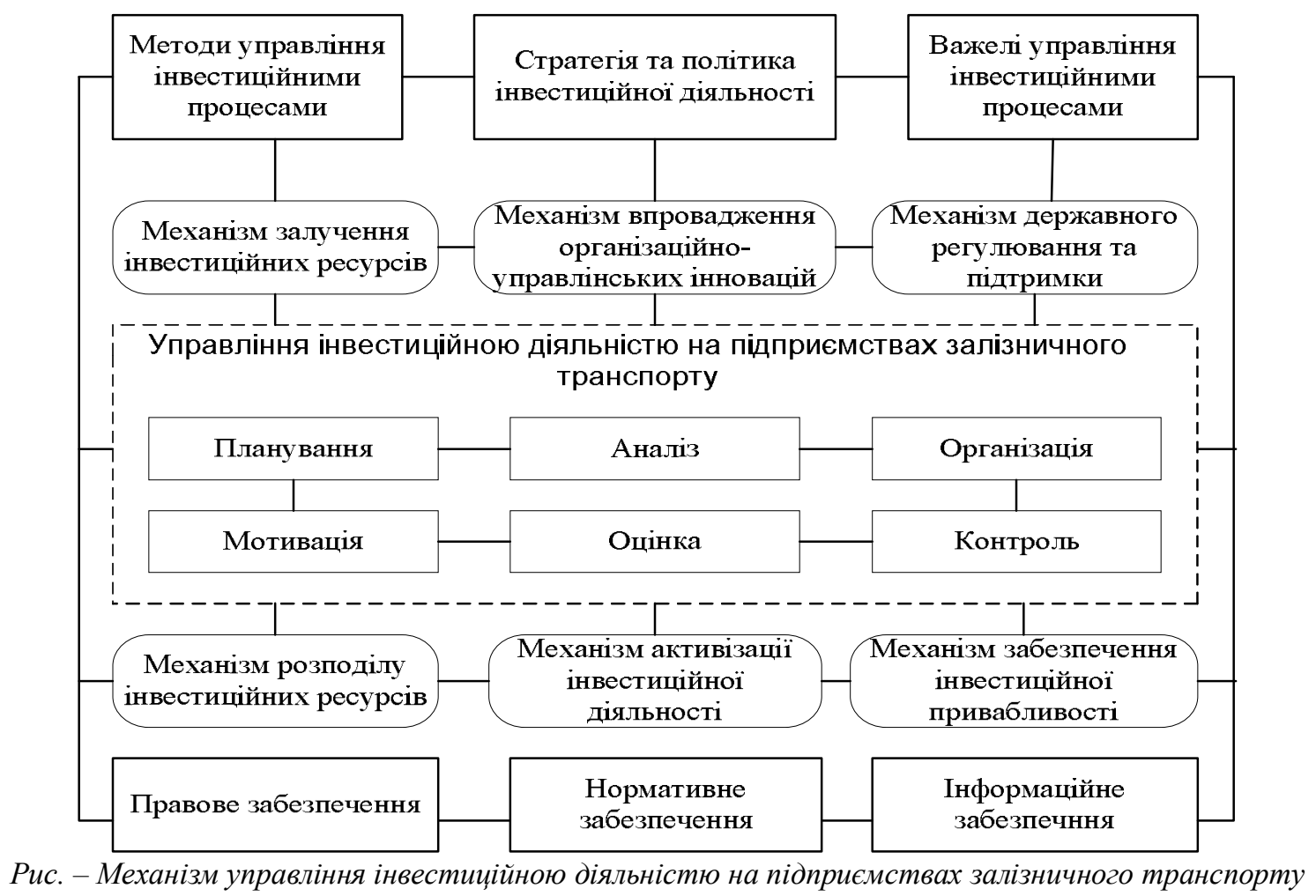

Забезпечення сталої роботи залізничного транспорту залежить від своєчасного та достатнього забезпечення інвестиційними ресурсами. До основних джерел фінансування інвестицій на залізничному транспорті належать: власні кошти залізниць і структурних підрозділів (прибуток, амортизаційні відрахування); кошти державного i місцевого бюджетів, які можуть надаватися на зворотній та незворотній основі, а також у вигляді податкового кредиту, дотацій, субсидій або компенсації частки банківського відсотка за наданими кредитами; кошти позабюджетних фондів; кредити банків та інших фінансових установ; облігаційні позики; кошти іноземних інвесторів; лізинг.

Форми державної підтримки передбачають: надання фінансової допомоги у вигляді дотацій, субсидій, субвенцій, бюджетних позик; реалізації заходів щодо розвитку та захисту економічної конкуренції; реалізація стратегії роздержавлення і приватизації власності; проведення політики ціноутворення тощо.

Важливою особливістю інвестування на залізничному транспорті $\epsilon$ змішаний метод інвестування, певний вид диверсифікації джерел, поєднання різних форм фінансування проектів тощо. В цілому всі методи інвестування можна поділити як такі, де використовуються посередники (держава, приватні інвестори, змішане фінансування) та не використовуються (повне самоінвестування). Останні внаслідок браку власних фінансових ресурсів залізницями використовуються обмежено.
Негативно впливає на інвестиційну діяльність існуюча централізація управління залізничним транспортом, яка призводить до того, що рух інвестиційних потоків усередині залізничної системи також носить централізованоперерозподільчий характер і диктує специфічний механізм формування й розподілу інвестиційних ресурсів. Основними недоліками такої схеми є: недостатня фінансова прозорість фінансовоінвестиційної діяльності; обмежені можливості залучення приватних інвестицій; дискримінаційне відношення при розподілі інвестиційних ресурсів.

Для активізації інвестиційних процесів на залізничному транспорті вирішальне значення мають такі заходи: розвиток механізмів державних гарантій, збільшення обсягів державних інвестицій; подальше удосконалення програмних завдань всебічної структурної перебудови економіки галузі на перспективу; здійснення координації напрямків діяльності інвесторів та застосування нових ринкових схем та механізмів їхньої участі в інвестуванні інноваційних програм та проектів галузі; залучення до фінансування інноваційних розробок, орієнтованих на створення перспективних об’єктів залізничного транспорту, впровадницько-інноваційних фірм - фірм ризикового (венчурного капіталу), як нового для галузі джерела інвестиційних ресурсів; розробка привабливих для потенційних інвесторів інноваційних проектів, впровадження маркетингових підходів до пошуку та залученню інвестиційних ресурсів. 
Важливим фактором отримання додаткових інвестицій є підвищення інвестиційної привабливості підприємств залізничної галузі. Для цього необхідно збільшити їх капіталізацію; створити стабільну та спрямовану для інвесторів законодавчу базу; підвищити інвестиційний рейтинг; забезпечити рентабельну діяльність підприємств залізничного транспорту.

Для вирішення означених проблем інвестування необхідне удосконалення самого механізму інвестиційної діяльності в галузі - всіх його складових (в тому числі інституцій), що приведе до його спрощення, здешевлення в утриманні, прозорості діяльності, маневреності, розбюрократизації. Крім того, необхідний перехід інвестиційного механізму в більш гнучку, мобільну форму функціонування, що сприятиме його відповідності сучасним умовам господарювання.

Висновки. Ефективний механізм управління інвестиційною діяльності на підприємствах залізничного транспорту дає змогу 3 максимальною швидкістю досягти поставлених цілей та вирішити основні завдання, сприяє результативному виконанню конкретних функцій управління інвестиційною діяльністю, повна i послідовна практична реалізація яких є надійною запорукою активної інвестиційної політики підприємств залізничного комплексу та їх результитивної господарської діяльності.

\section{СПИСОК ЛІТЕРАТУРИ}

1. Дикань В.Л. Забезпечення ефективності інноваційної діяльності підприємств залізничного транспорту: монографія / В.Л. Дикань, В.О. Зубенко. - Х.: УкрДАЗТ, 2008. - 194 c.

Рецензент д.е.н., професор УкрДАЗТ Кірдіна О.Г.
Експерт редакційної колегії к.е.н., доцент УкрДАЗТ Зубенко В.О.
2. Ільчук В.П. Інноваційно-інвестиційні системи залізничного транспорту: становлення та розвиток / В.П. Ільчук; За ред. д.е.н., проф. Сича Є.М. - К.: Логос, 2004.- 381 с.

3. Калініченко Л.Л. Вирішення інвестиційної проблеми інноваційного розвитку підприємств залізничного транспорту / Л.Л. Калініченко // Економіка: проблеми теорії та практики: 3б. наук. праць. - Дніпропетровськ: ДНУ, 2008. - Випуск 236, Т. 2. - С. 222 - 227.

4. Андрєєва О.В. Чинники ефективного інвестування залізниць в умовах динамізації циклів економічного розвитку / О.В. Андрєєва // Вісник транспорту і промисловості. - 2012. - № 39. - С. 83-88.

5. Лоза С.П. Можливі джерела фінансування інвестицій в залізничний транспорт України / С.П. Лоза // Проблеми розвитку зовнішньоекономічних зв'язків і залучення іноземних інвестицій: регіональний аспект. Збірник наук. праць. - Донецьк, ДонНУ, 2007. - С. 1442-1451.

6. Долгий А.О. Механізми державного регулювання процесу інвестування залізничної галузі [Електронний ресурс] / Долгий А.О., Долгий О.О., Манзюк В.В. // Науковий вісник. - 2009. Вип.3. - Режим доступу: http://www.lvivacademy.com/visnik3/fail/+Dolhiy.pdf

7. Инвестиционная деятельность / Н.В. Киселёва, Т.В. Боровикова,

Г. В. Захарова и др. - М.: КНОРУС, 2005. - 432 с.

8. Черваньов Д.М. Менеджмент інвестиційної діяльності підприємств: навч. посіб. / Д.М. Черваньов. - К.: Знання-Прес, 2003. - 622 с.

9. Аюпова Л.К. Содержание организационно-экономического механизма инвестиционной деятельности промышленных предприятий / Л.К. Аюпова // Экономические науки. - 2007. - №8 (33). - С. 260-264.

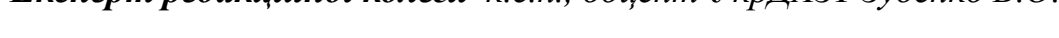

УДК656.07.001.76

\title{
ЗАБЕЗПЕЧЕННЯ ЕФЕКТИВНОСТІ ІННОВАЦЙННӦ̈ ДІЯЛЬНОСТІ НА ПДПРИЕМСТВАХ ЗАЛІЗНИЧНОГО ТРАНСПОРТУ
}

\author{
Зубенко В.О.,к.е.н., доцент, \\ Коник Л.Ю., магістр (УкрДАЗТ)
}

В статті обтрунтована необхідність інноваційного розвитку підприємств залізничного транспорту. Досліджені існуючі наукові публікації з питання інноваційного розвитку підприємств галузі. Визначено, щзо ключовою ланкою в питанні забезпечення ефективності інноваційної діяльності підприємств залізничного транспорту Украӥни, з урахуванням сучасних умовах господарювання, $\epsilon$ 